\title{
Varieties of a Law-Governed State
}

\author{
Valentin Yakushik \\ Doctor in Political Sciences, Ph.D. in Law, Professor, National University \\ of "Kyiv-Mohyla Academy" (Ukraine) \\ E-mail: yakushik@hotmail.com \\ https://orcid.org/0000-0002-1747-0151
}

The article presents an attempt to construct a comprehensive typology of a law-governed State. Multifocal, multidimensional approach is used to present a wide range of varieties of concepts and functioning models of a law-governed State. Materials contained in the present article have been used in the teaching process at the University of "Kyiv-Mohyla Academy" (Ukraine) and are available in Ukrainian and Russian languages for Ukrainian students and researchers. The author hopes that the updated English version of these theoretical materials may be useful for a wider international audience.

Keywords: State; law-governed State; rule of law

Received: November 29, 2018; accepted: December 17, 2018

Ukrainian Policymaker, Volume 3, 2018: 72-84

https://doi.org/10.29202/up/3/10

\section{Introduction}

A goal of democratic development of Ukraine as an important socio-political component of Europe and Eurasia unites various cultural and political forces of this country and the most important entities of the world. Nevertheless, there are a number of contradictions between their practical aspirations and the cumulative result of their interaction. Neither people at large - the citizens of Ukraine, nor the absolute majority of political forces, both inside and outside the country, are happy with the current objective results of political development of independent Ukraine.

The major objective of this article is to hint at the essential contradictions between the Western liberal-democratic notions of the rule of law, or a law-governed State ("Rechtsstaat", in German; "État du droit", in French; "Estado de Derecho", in Spanish) and the corresponding State and legal concepts and practices, on the one hand, and the actual operational principles of the post-Soviet society (primarily, of the State institutions and of political and legal consciousness) in contemporary Ukraine, on the other.

The author of this article holds in respect the widely spread methodology of promotion of the pure type of liberal democracy and the currently still prevailing concepts of transitology -

(C) Yakushik, Valentin, 2018 
transition from totalitarianism to democracy via a certain phase of authoritarianism. However, while using the tools of distinguishing pure types, in the analysis of a law-governed State, the author considers it appropriate to begin with contrasting to each other such three pure types of the State as: 1) law-governed State; 2) police State (or arbitrary State), and 3) revolutionary State. In this regard, the author is of the opinion that in the present-day Ukraine there are certain manifestations of the elements of each of the abovementioned pure types, and this objectively present unique mix creates a lot of problems for the supporters of "hard dichotomies" in interpreting the nature of a post-Communist, post-Soviet society in Ukraine.

The article presents an attempt to construct a comprehensive typology of a law-governed State. Multifocal, multidimensional approach is used to point to a large spectrum of the existing concepts and functioning models of a law-governed State.

Material for this article was prepared on the basis of studying of a wide range of academic and political literature on the subject of a law-governed State and the rule of law, and consolidation of practical political experience in the functioning of political and legal institutions of a number of countries, including the present-day Ukraine, interviews with experts in various fields of law, law-making and law enforcement. Some materials contained in the present article have been used in the teaching process at the University of "KyivMohyla Academy" (Ukraine) and are available in Ukrainian and Russian languages for Ukrainian students and researchers [Yakushik, 1993: 177-195; Yakushik, 2012: 14-27]. The author hopes that the updated English version of these theoretical materials may be useful for a wider international audience.

\section{Typology of a Law-Governed State}

Virtually any political term can be understood and interpreted by the representatives of different trends of political and legal thought in a different (and sometimes totally opposite) way. The same is true of the "law-governed State" term, which in various theories is used for substantiating quite differing political and social institutions.

Proceeding from the most popular typology of political and legal doctrines [see, e.g.: Shively, 1991: 43-59; Yakushik, 1991b: 174-176, 182-184], the following classification of the concepts of a law-governed State (and the corresponding theoretical and functioning models of political structures) can be proposed:

1. Liberal-democratic, that stipulate for the existence of democratic political system and market economy with substantial involvement of the State in economic life of the society.

2. Conservative-democratic, characterised by the defence of the institutions of political democracy and market-based economy with the reasonable need for maintaining a minimal role of the State in the control of socio-economic relations.

3. Social-democratic. Fundamentally they are similar to liberal-democratic, but they stipulate for a larger spectrum of socio-economic rights and freedoms of citizens, give more consideration to the development of direct democracy and advocate the idea of socialism as an alternative to capitalism.

4. Radical left (revolutionary-communist, left socialist, revolutionary-democratic, etc.) that allow for the preservation of certain institutions of authoritarian and/or autocratic power in the transition phase and completely or to a large extent negate the value of the market-based economy mechanisms. 
5. Radical right (fascist, Nazi, etc.) characterized by the defence of dynamic autocratic, totalitarian power as a socio-political ideal.

6. Traditionalist (national-conservative, "nomenclative"-conservative and other) that ensure preservation of stagnating, static institutions of undemocratic power.

This classification is based on two major criteria: qualitative differences between the existing institutions of a) political and b) economic power. However, is there anything else, apart from the general term itself, which unites all the varieties of a law-governed State theories? Are there other typologies of the State that can constitute efficient means of description and cognition of politico-judicial institutions? To be able to answer these questions we have to indicate the major general ideas (principles) of any law-governed State concept, to begin with.

Synthesis of postulates of various law-governed State theories provides basis for the conclusion that such ideas (principles) are as follows: 1) the prevention of anarchy in social relations by the State, and 2) the exclusion of the (extra-legal) abuse of power on the part of the State and predominance of methods of regulatory control in State activities or (in case of providing some restrictive construction of this principle in degraded and dehumanized versions of a law-governed State concepts) - obligatory execution of the State arbitrariness in legal form through the exercise of the State activity on the basis of the laws in force (the sources of norms that in the opinion of the State have the highest legal force).

Taking into consideration the existing differences in the perception of the law and/or the State mechanisms, capable of preventing general anarchy, as well as the abuse of power, we can introduce various typologies of a law-governed State. Herewith it would be appropriate to use a pluralistic (multifocal, multidimensional) method of analysis of the essence and the structure of political and legal institutions.

Of course, researching the topic of a law-governed State and creating new or analysing existing typologies, we should not limit ourselves to the differentiation between law-governed and police State (or, alternatively, law-governed and constitutional State) as specific types of the State. It is also important to construct and use typologies of different law-governed States - of various theoretical models and the actually functioning systems of political and legal institutions, defined by this term.

Based on the Marxist concept of socio-economic formations, a Spanish lawyer Elías Díaz distinguishes the following historic types of a law-governed State: 1) liberal (in the period of classical liberalism); 2) social-liberal - corresponding to the period of neo-capitalism and institutions of the "Welfare State"; 3) democratic — ensuring implementation of the "Western way to democracy and socialism" [Díaz, 1984: 11-20]. A similar theoretic approach is used by many lawyers, political analysts and practicing politicians who adhere to democratic socialism concepts.

Meanwhile, not all supporters of democratic socialism consider socialism as a mandatory stage in the development of human society in general and of each of local or regional civilizations, in particular. Hence, the "historical types" listed above, in fact, become the ideal ("pure") types of a law-governed State.

A Portuguese constitutionalist lawyer Marcelo Caetano distinguished two major models of a law-governed State - liberal and social, and used the notion of "historic form" to define them. The notion of "ideal type" was used by him just for characterising the law-governed State in general, as opposed to such ideal type as politico-administrative State "where the law is used by the State in a mere instrumental capacity" [Caetano, 1983: 324-325]. It is noteworthy that Caetano considers the social law-governed State as a "mixed form that includes elements 
of both law-governed and politico-administrative State", because social State "by means of developing the extra-legal functions and frequent use of legal functions as an instrument for exercising extra-legal functions" "is converging with politico-administrative State" [Caetano, 1983: 325-326]. Caetano, like many other West European and North American lawyers and political analysts, does not actually distinguish between the "form" and the "type" terms.

Social scientists and politicians that challenge the idea of socialism, as a rule do not consider problematics that the socialists and social-democrats include into the concept of democratic law-governed State [see, e.g.: Lucas, 1955]. This being the case, modern liberals (unlike the majority of neo-conservatives that quite often refer to themselves as neo-liberals, since in the field of economics they mainly adopt the classic liberal attitude of "the night watchman State" theory) essentially assess the social law-governed State as a perfect form or the highest stage of development of a law-governed State. However, followers of modern humanistic socio-political theories most often point out historic limitations of the currently existing neo-capitalist type of technical civilization and the corresponding (to this type) social law-governed State. At that, like Russian philosopher and poet Daniil Andreyev, they state that in the future "issues of technology and economy will cease to be the focus of prime attention..., and human talents shall turn to other things: the things driven by the thirst for knowledge, by the love to all the creatures alive under the sun, the need for the highest forms of creativity and love for beauty" [Andreyev, 1993: 21].

The abovementioned problematics of the historic types of a law-governed State can be extended by extrapolation into the future of various visions of the development of the modern societies and the possibility of emergence of new types of civilizations, based on fundamentally different (as compared to the current ones and those that existed before) moral and ethical principles and values of social development. These new types of civilizations will use organizational models and models of managerial structures functioning that have been unknown in the preceding practices and, possibly, seen to be Utopian today. Besides, this problematics can include historic experience of democratic political systems of Antiquity (first of all, Athens and Ancient Rome) and the Middle Ages, some regimes of "enlightened absolutism" (or "benevolent despotism") when the bearer of the absolute power uses that power to protect the good of the people; and some other models of political and legal regimes.

Here we can differentiate the following historic types of a law-governed State that guarantee major rights and freedoms of full citizens:

1. Slave-owning law-governed State, though not only ancient one. It also includes slaveowning capitalist State, similar to those that existed in the Southern States of the United States of America before slavery was abolished there after the North won the civil war. In this case the criterion for distinguishing the abovementioned type (as well as the ones to follow) is not the character of "economic basis", but legal and actual status of major social strata and groups of population of a specific country, the presence or absence of privileged strata and the character of their privileges.

2. Nobiliary law-governed State - which does not obligatory mean being a feudal State. Primarily, a feudal State can be (similarly to the free cities of the Middle Ages) not nobiliary but of a corporate and guild type, and, secondly, the nobility can be not only feudal, but also of a "barrack-socialist" type (the so-called "nomenclature"). Elías Díaz is of opinion that one cannot state that there was a "nobiliary law-governed State" because in the Middle Ages the "sufficient legal institutionalization" of relationship between the Crown and nobility was absent [Díaz, 1984: 25-26]. Though, whatever 
weak (from the point of view of the modern liberal-democratic standards) institutional guarantees of the equal status of a certain part of the inhabitants of the majority of countries in the Middle Ages might have been, it still has to be recognized that such guarantees were present here and there (for example, in England and Poland). Besides, the guarantees of the "szlachta"(a legally privileged noble class) rights in Poland were not in the least less real (though in many cases absolutely different) than the mechanisms of securing rights and freedoms of citizens in modern democratic countries. It is not viable to consider all the major components of the modern types of a law-governed State as mandatory for each of historic types of a law-governed State. Otherwise, by means of adhering to such "restrictive" research orientation, we drastically curtail the number of distinguished historic types (though this is also one of the entirely acceptable theoretical positions that has its cognitive and descriptive value). Slave-owning, nobiliary and some other varieties of a law-governed State - ethnocratic (where the power belongs to the "elite" ethnic group), or religiocratic (where a particular religious denomination pretends to exclusively exercise the authority), etc. - can be aggregated under the definition of a caste and/or qualification quasi-liberal (quasi-liberal from the purely legal point of view, but not necessarily from the point of view of economy) lawgoverned State that declares formal legal equality of all full citizens, but is based on the gender, racial, national (ethnic), tribe, clan, religion/denomination, social origin, class, income, place of birth and other criteria that exclude from the active political life large strata of the adult population of the country, i.e. introduces (institutionalizes) strictly separated from each other strata that differ by the legal status of their members. At that, transition from one particular personal (and/or group) status to another is either impossible or very complicated.

3. Liberal law-governed State with the complete formal legal equality of all full citizens and the absence of pronounced legal discrimination of major social classes and groups of adult population of the country.

4. Social (i.e. neo-capitalist liberal democratic) law-governed State complements the features of a liberal law-governed State with securing certain guarantees of wellbeing for the poor and disadvantaged classes/strata in the country. This concept was formalised, for example, in the Constitution of the Federal Republic of Germany adopted in 1948 (Article 28), where the term of "democratic and social law-governed State" ("democratic and social state governed by the rule of law") [Basic Law, 2018: 31 is introduced, as well as in the Constitution of Spain in 1978 (Article 1) where the notion of "social and democratic law-governed State" [Las Constituciones, 1981: $284]$ is also applied. It was further reflected (as "democratic, social, law-based state" wording) in the Preamble and in the Article 1 of the Constitution of Ukraine adopted in 1996 [Constitution, 1996: 1].

5. Democratic law-governed State (as per above cited interpretation by a number of theoreticians of the modern social-democracy of Romance-speaking countries), which is sometimes referred to as socialist in the wording of the left-wing ideologists of the social-democratic movement [see: Uma via, 1974: 6; Díaz, 1982: 203, 220, 223], which facilitates progressive "overcoming" of capitalism (neo-capitalism) and replacing it with a more humane and socially efficient society of democratic socialism, providing a fair level of material and spiritual life of all the strata of the society and minimises limitations imposed by the objectively existing differences of class nature. (Of course, 
this type of concepts of socialist law-governed State should not be identified with the official theories of the same name that were publicized on a large scale in $80 \mathrm{~s}$ in USSR, Bulgaria and some other former "socialist" countries). Concept of democratic law-governed State is formalized in the Constitution of Portugal 1976 that can be explained by the determinative influence of political and legal ideology of democratic socialism on the process of working out of this Constitution and its subsequent revision [Yakushik, 1986: 34-38]. It should be taken into account that in a number of cases the idea of democratic law-governed State is equated (by the modern liberals) to the concept of social (i.e. neo-capitalist) State. Simultaneous use of the terms "democratic" and "social" (in any sequence) to characterise a law-governed State in the framework of its neo-capitalist liberal interpretations differs from social-democratic renderings of democratic law-governed State, first of all, by the scope of meaning in the notion of democracy. Comparing these two theoretical approaches - liberal and socio-democratic (socialist), Elías Díaz emphasised that "a wide, integral (socialist) understanding of democracy... is capable of adding a deeper and more realistic meaning from the point of view of freedom and equality... to the other, more narrow (liberal) understanding of democracy... that is limited almost exclusively, or in any case predominantly, by legal and political aspects of this problem" [Díaz, 1982: 208].

6. Humanistic law-governed State that specifically secures all-round development of an individual and thoroughly takes into account interests of all social strata and groups of population and the needs of both present generations and generations to come.

Within the framework of this theoretical approach, apart from the "pure" types noted above, we can differentiate mixed and transitional types of a law-governed State that guarantees major rights and freedoms of full citizens. The typology under consideration does not include degraded law-governed State models similar to those that existed in Nazi Germany or during the dictatorial regime of Augusto Pinochet in Chile under the conditions of the so called "authoritarian democracy that protects and integrates" [Pinochet, 1977], because such "law-governed States" do not fulfil the function of securing major rights and freedoms of full citizens but pursue other objectives (not related to the implementation of the idea of inherent worth of an individual), such as "revival of the grandeur of the nation", "renewal of civilization", etc.

One of the major classifications of a law-governed State doctrines consists in making the distinction between: 1) formal positivistic concepts where the idea of a law-governed State is brought down to the idea of "the legality State", "that fulfils its purposes with the assistance of legal means" under the conditions when "the purposes of the State may change according to the selected policy line" and 2) material, natural law concepts where "political power is considered as a means of implementation and assurance of the natural personal rights that are the source of any legal order" [Caetano, 1983: 320-321, 323].

This quite clear theoretic basis allows for the easy differentiation of such types (or varieties) of political and legal institutions that existed in the past, are in existence now, and quite possibly will have a place in the future, and are corresponding to the formal, positivist model of a law-governed State:

1. States, antidemocratic in their substance and form, with the purely formal "regime of legality" that stipulates for the mandatory legal formalization of the State arbitrariness and strict adherence to the current antidemocratic legal norms. Within the framework of the classification under consideration such "law-governed" States are set against 
antidemocratic "non- law-governed" ones, that have nihilistic attitude towards the use of the legal form to give general validity to their acts of volition, as well as to all other types of State that are not capable of providing for the legal predictability of the power structures activities and/or preventing anarchy in the regulation of social relations. This type of a "law-governed" State can list: a) some radical right-wing regimes, for example, Nazi Germany within the territory of "Reich proper", and not its "possessions" and as applied only to the "Aryan race representatives"; b) a number of radical left-wing totalitarian regimes that preserved a considerable share of traditions characteristic to the European continental or Anglo-Saxon legal culture (legal technique, primarily); c) conservative-stabilizing antidemocratic regimes — from traditionalist oligarchic regimes that are well known from the political practices of Latin America to the stagnating "barrack-type" socialist regimes that existed up till the end of the 1980s - beginning of the 1990s in the countries of Central and South-Eastern Europe and in Northern Eurasia.

2. Autocratic or/and authoritarian regimes that guarantee a sufficiently wide scope of personal and civil (quite often also socio-economic) rights, but do not introduce an integrated system of democratic bodies of the constituent and legislative power. We can consider the following examples: a) a number of "enlightened absolutism" regimes, including modern Kuwait and Qatar, and to a certain extent the Ancient Indian State in the late period of reign of Ashoka of the Maurya Dynasty (after Ashoka's Buddhist conversion till $232 \mathrm{BC}$ ); b) some revolutionary regimes in the developing countries that implement anti-totalitarian, anti-oligarchic, anti-imperialistic, anti-ochlocratic strategies aimed at empowerment (permanent expansion of the rights and freedoms) of citizens and setting up the conditions for the country to take up a worthy place among other nations in the world. Such States can be characterised as autocratic or/and authoritarian meritocracies, i.e. as the power of the "worthy" people (wise, highly qualified politicians and other professionals that possess required knowledge and practical managerial skills and high moral stature) that are vested with genuine trust (though it is not always expressed by means of voting) and are respected by their fellow citizens.

3. Typical democratic States that necessarily have within their mechanism an intrinsic formal legal, positivist component of the "legality State".

Descriptions of political and legal institutions, relevant to the material, natural law concepts of a law-governed State, that are most popular in the countries of Western Europe and other regions of the world which are under their prevailing cultural influence, contain the following elements:

1. "The rule of law" which is "the expression of common will" and "the legal nature of the State administration activities" [Díaz, 1984: 31]. In a different wording this element of a law-governed State is defined as "the principle of democratic law" stipulating for the "formal subordination to the law", "democratic mechanism of law-making" and "democratic purview and content of the law" [Constituição, 1976: 167], as well as "the power's lack of discretionary authority" [Fernandes, 1974: 44-45] (i.e. lack of authority to act on the basis of one's own perceptions of political expediency).

2. Independence and "separation of powers - legislative, executive and judiciary" [Díaz, 1984: 31].

3. "Formal and legal guarantees and efficient practical implementation of major rights and freedoms" [Díaz, 1984: 31]. 
4. Responsibility (inclusive of legal liability) of government agencies and officials for their actions [Caetano, 1993: 322].

Most frequently, contemporary European lawyers also indicate some singular characteristics of a law-governed State, related to the absolutization and universalization of certain institutions, common and traditional to the modern West European civilization. Thus, for example, the supposedly generalizing definitions of a law-governed State (relevant to its material, natural law interpretation) often include the following provisions: 1) "the legislative power ... should be set up on the basis of free elections of the people's representatives under the conditions of multi-party system"; 2) "the executive power should represent the majority or, in case of a coalition government, various trends of political thought"; 3) "the judiciary should be formed through the contests for the posts, or even by the election of judges by the judges from their own midst, but in no way on the basis of the decision or initiative of the executive power" [Fernandes, 1974: 44-45].

The above stated was formulated by a Portuguese socialist lawyer and politician Vasco da Gama Fernandes, though it is a typical kind of wording for a considerable number of European and Latin American lawyers, political analysts and politicians (social democrats, liberals, conservatives and apolitical pragmatists). Another typical statement is that in a law-governed State the laws must be ordained by the supreme representative authority, and the by-laws of the executive agencies must be issued on the basis and in the abeyance of laws [Baglai, 1989: 43; Tikhomirov, 1989: 160-166].

All these and similar theoretical provisions are essentially and primarily backing the declaration of the following general principles of a law-governed State:

1. The State being limited by the legislation in force, and the State agencies are prohibited from acting contrary to legal norms.

2. Democratic content of the legal norms in force, i.e. securing ample rights and freedoms of the citizens and democratic mechanisms of exercising power.

3. The supremacy of laws in the system of sources of law.

4. Democratic law-making procedures (in the establishment or authorization of legal norms).

5. Institutional and normative guarantees of the efficient implementation of democratic rights and freedoms of citizens as well as efficient functioning of the State mechanism and political system in general - prevention of anarchy in the society, responsibility of the State agencies and officials for trespassing the law, responsibility of all legal entities (individuals and organisations) for the offenses committed by them, guarantees against the autocratic degeneration of power.

Quite secondary by nature are specific organizational and technical structures that contain multitude of civilizational and sub-civilizational, regional and national particularities, as well as purely situational (that are of temporary, fleeting political nature, unrelated to deep cultural and historic traditions of a specific society) differences in interpretation of virtually each of the listed principles.

Generalizing major possible groups of a law-governed State typologies, we should note some of interpretations that are related to the absolutization and universalization of local (national and regional) experience and in this way provide basis for distinguishing specific models (or types) of a law-governed State.

I. The real or fictitious nature of the limitations on the State (defined as a law-governed) imposed by the legislation in force allows for the States to be conventionally subdivided into 
the abovementioned: a) "material" law-governed States, limited not only by the laws, but by law proper in its "natural law" perception, i.e. by the unalienated human rights and the rights of nations; and b) "formal" law-governed States that are bound just by the requirement to use the legal form to give mandatory validity to their acts of volition.

II. Specifics of interpretation of the laws' democratic content, that depends on a particular understanding of democracy [Yakushik, 1991a: 138, 145, 148-149], forms the basis either for distinguishing various historic types of law-governed State, or for contrasting two major ideal ("pure") types of law-governed State: a) States that to the maximum extent implement the principle of legal equality of an individual, and b) aristocratic (estate, caste, qualification, etc.) States that maintain a rigid division of society into estates whose representatives strikingly differ in terms of their legal status (scope of rights, freedoms and duties).

III. Substantial differences in interpretation of the principle of the supremacy of law and democratic character of law-making procedures (first of all, of the legislative process) in various countries actually indicate the existence of such types of a law-governed State as:

1. Law-governed State that corresponds to the Eurocentric interpretations of the idea of the hierarchical pattern of law or, more precisely, - its interpretation in the spirit of the modern European continental family of legal systems [David, 1988: 41, 49]. This theoretic approach is characterised by the obligatory ascription to a law-governed State of the existence and priority (in relation to other sources of law) of the law embodied in the form of normative acts that have the highest legislative force and are approved by the highest representative bodies. Sometimes in this respect there may be introduced an addendum indicating that the laws can also be approved by popular vote (referendum).

But in the countries that belong to other families of legal systems, the external form of expression and the structure of the sources of law may be different and even differ radically from the patterns that have become customarily and traditional for the continental Europe with its particular, though in many cases domineering in the modern world, legal technique. Can it be true that all other models of legal norms hierarchy should be considered as characteristic to the non-law-governed states only? For sure, it is possible to operate in such a manner, or almost in such a manner, because choice of approaches and methodology is virtually almost always left to the researcher, to the interpreter. Nevertheless, it seems quite reasonable to suppose that it would be better just to discard some absolutizations of the partial (regional) experience.

2. Law-governed State where alongside with the laws, issued by the highest representative body, the top position in the hierarchy of sources of law also belongs to the judicial precedents set, first of all, by the Constitutional and/or the Supreme Court, and to legal customs and (possibly) laws approved by the highest legislative body that is not representative by its nature - it can be, for example, a monarch or a special extraordinary governing institution [Yakushik, 1991a: 138, 145, 148-149].

3. Law-governed States with their traditional systems of religious and customary law, where part of traditional (religious and customary) norms are put in the hierarchy of the legal norms above the legislative acts (even above the written Constitution, if there is one).

4. Law-governed States where legal regulation by means of individual (non-normative) acts prevails over normative legal regulation.

It should be noted that virtually in any of the considered types of law-governed State there can exist a practice of "delegated legislation", i.e. issuing of normative acts with the highest legal forth not by the highest legislative body, but by any other institution of 
power, authorised by the highest legislative body or by referendum. Herewith there can be a requirement introduced for a mandatory subsequent approval of such acts by the highest legislative authority. In some cases such approval can take place before the issuance of the respective act.

Besides, taking into account specifics of the supremacy of law principle and the nature of law-making procedures, but now on the basis of criteria of the presence or absence of a unified legal system in the country, the following law-governed States may be distinguished: a) with a unified legal system of the entire country; b) with specific legal systems existing in different regions of the country; c) with several specific legal systems that do not have (according to the general rule) a specific "regional tie-in" within the country, but are functioning simultaneously throughout its territory, with the extension of each of these legal systems on certain categories of citizens depending on their religious/denomination or ethnic belonging.

IV. Based on the particularities of the State mechanism (capable of preventing both anarchy in the society, and autocratic degeneration of power) we can distinguish the following ideal types of law-governed States: a) those that apply "classical" system of separation and independence of powers and their "checks and balances" (by models of the USA or France); b) States, providing unconditional supremacy of their parliament over the executive (Britain, India, Japan) with exclusively (or predominantly) ceremonial role of the head of State; c) those that apply a range of classical schemes of separation of powers, but at the same time widely use (inclusive in law-making activities) procedures of direct democracy (Switzerland); d) theoretically it is quite possible to have a State where both legislative and executive powers are concentrated in the hands of one body that is reporting and accountable to the people and quite often is subjected to the official procedures of defining the degree of trust and support of its current policy with the immediate legal consequences. One of the examples of such system can be a quasi-monarchy model, suggested by Jean-Jacque Rousseau.

There is no doubt that this theoretical design will be far from complete, if we do not take into account mixed and transitional types.

The idea that the participation of political parties in the formation of legislative bodies is a prerequisite for the existence of a law-governed State is quite common now. The aforementioned statement by Vasco da Gama Fernandes is one of the manifestations of such a settled thought. However, here we are also faced with the universalization of one of the possible (albeit the most widespread) methods in contemporary political systems. The whole range of examples (bailiwick of Guernsey, bailiwick of Jersey, Isle of Man, etc.) give evidence that even in the countries with democratic political culture and pluralistic mechanism of exercise of power the traditions of struggle between the parties and even political parties themselves may be absent. Also, the concept of direct democracy with no place for political parties that had been substantiated by Jean-Jacques Rousseau, is not a pure Utopia either.

Consensual model of democracy (as opposed to the confrontational model) is capable of founding itself on prevailing interaction not of political parties, but professional and local communities, as well as individuals and non-party organizations that are expressing and representing their interests. In some societies (in certain cultural environment and under certain circumstances) the role of "classical" political parties can be playes by trade unions and employers' organizations, various factions within the State apparatus, youth associations, and probably tribal, clannish and similar structures. 
Thus, it would be rational to differentiate law-governed States: a) that exist in societies with the established multi-party system, and b) in societies with the lack of multi-party traditions and the absence of political parties as such.

Taking into account the diversity of existing and possible models of ensuring the genuine independence of the judiciary through organizational and technical means (though not limited to these means), the specificity of the way of election or appointment of judges can be chosen as a criterion for the classification of law-governed States. Hereon, within the framework of this theoretical approach we can distinguish in particular such types (or varieties) of a law-governed State: a) with the system of appointment of judges for life by the head of State; b) with judges taking their positions through the contest for the post (the contest being organised by the judiciary), or as a result of direct election of judges by the judges professional community; c) with judges elected directly by the citizens or by all legally cabable/competent permanent residents of the relevant judicial district.

Claiming for a greater comprehensiveness and completeness of the considered classification, the researcher should take into account other existing or theoretical models of the judiary and expand the list of the types (varieties) of the same order (that is, distinguished on the basis of the same criterion) of a law-governed State.

It should be noted that the absence in a number of countries of an integrated (or, more precisely, single) legal system operating across the territory and/or for the entire population of the country is often combined with the absence of an integrated (single) judicial system. Thus, such specificity of judicial systems gives grounds for the differentiation of separate types (or varieties) of a law-governed State in the same way as the one used above to distinguish the types of law-governed States by the criterion of the absence or existence of a unified legal system in the country.

Considerable cognitive and descriptive role is played by the distinction of a) stable and b) unstable law-governed States, based on the systemic condition of the society in general and/ or status of political system in it. Besides, it is of substantial importance to understand that law-governed States that act a) under normal and b) under extraordinary circumstances can have qualitatively different systemic characteristics and, in particular, specific (inherent to them under such - normal or extraordinary - circumstances) organizational and functional structure and different constructive potential (in reference to specific conditions of time and place). This provides ground for the introduction of the relevant typology of a law-governed State that stipulates for the presence of two major types and a multitude of varieties within each of these types. Of course, the indicated criteria (characteristics) of "normality" and "extraordinarity" of the situation - political, economic, environmental, cultural, etc. (both in its national, i.e. relevant for a specific country, and in international context) can vary to a considerable extent depending on the research, educational, propaganda and other purposes of the creators and promotors of such typologies.

Diversity of models (types and varieties) of a law-governed State, multidimensionality and multi-aspect character of its possible classifications (typologies) and periodisations of development must be taken in all seriousness by the theoreticians of the State and law, academics from other fields of political and legal studies and by practicing politicians. Especially this concerns the representatives of young independent States with a relatively limited historic experience of functioning of pluralistic democracy and with insufficiently deeply rooted democratic political culture. 


\section{Conclusions}

Distinguishing various types and sub-types (models) of a law-governed State, i.e. understanding peculiarities of different institutional arrangements leading to guaranteeing the principles of the rule of law, equality before the law and unbiased and fair implementation of law, one should not exclude the further search for new efficient models of democratic institutions to function in Ukraine. For sure, as an ancient Greek tragedian Aeschylus said, "in war, the first casualty is truth" [Aeschylus], but difficult times presuppose full moral responsibility of genuine responsible actors. We are going through a challenging stage of the society's and our personal life. In such an environment, the task for open-minded and creative political scientists and lawyers (if they are not just a part of manipulative efforts of the mainstream ideological trends, or of other "semi-blind" quasi-alternative trends to cover and/or simplify the realities and to raise a "onedimensional man" [Marcuse, 2002]), is to strive for the discovery of the often unexpected truths, and to help people practice thinking "outside the box", by their own brains and true practical involvement, to see beauty of the world in its diversity, complexity and plenitude.

The formation and maintenance of institutions of a law-governed State is only a part (though very important one) of the whole system of mechanisms guaranteeing democratic, humanistic and balanced development of the society in general and of all its major components. Among a number of means to efficiently approach the current crisis developments in Ukrainian politics it is worthwhile to mention the following:

a) The creation of a mighty "third forth" in the Ukrainian polity with a clear vision aimed at changing the old deep-rooted principles of self-reproduction of Ukrainian apathetic, torpid establishment (and its inbuilt soulless, dead-hearted alliance with the selfish interests of big business and foreign powers' influential entities), overcoming the existing latent internal and international "oligarchic consensus" vis-à-vis the present and the future of Ukraine, and finding a valid alternative to nepotism and corruption as a wicked backbone component of political and economic system.

b) Creating and promoting structures (forums) and processes providing for the "policies of truth" aimed at introducing mechanisms of responsible and mutually beneficial interclass partnership, achieving national reconciliation in cultural, inter-regional and civilizational spheres and its legal formalization based on the future referendum results, comprehensive new "national pact" leading to the relevant efficient and actually practiced constitutional changes.

c) Development and implementation of democratic mechanisms of public (nation-wide, regional and local) discussions ("public hearings") on the key issues of cultural, socioeconomic and political development.

d) Deconcentration and decentralization of power and practical introduction of the principle of subsidiarity in the relations between different layers of power.

e) Genuine democratization and normalization of the electoral process (in a wider sense - of the "constituent power" in general) and of the procedures and mechanisms of the judiciary.

f) Implementation of dynamic mechanisms of independent, responsible and fair constitutional control, as well as of the overall system of the "control power" and the "examination power" (overseeing the quality, reliability of civil servants and the development of their further potential) and of clearly-defined and transparent bodies (fora) of "conceptual power". 


\section{References}

Aeschylus. Agamemnon. Quotes. https://www.goodreads.com/author/quotes/990.Aeschylus Andreyev, Daniil. The Rose of the World (Roza mira). Moscow: Klyshnikov, Komarov \& Co., 1993. (In Russian).

Baglai, Marat. Law-governed state: from idea to practice. (Pravovoe gosudarstvo: ot idei k praktike). Communist, No 6, 1989: 38-47. (In Russian).

Basic Law for the Federal Republic of Germany. 23 May 1949. Last amended on 13 July 2017. Berlin: German Bundestag, 2018.

Caetano, Marcelo. Manual de ciência política e direito constitucional. Coimbra: Livraria Almedina, 1983.

Constituição da República Portuguesa. 1976 (anotada). Silva Lopes V. S.1.: Editus, 1976.

Constitution of Ukraine. Adopted on 28 June 1996. Official translation. https://www.kmu.gov. ua/storage/app/imported_content/document/110977042/Constitution_eng.doc

David, René. Major legal systems of today. (Osnovnye pravovye sistemy sovremennosti). Tranlsation from French. Moscow: Progress, 1988. (In Russian).

Díaz, Elías. Estado de Derecho y sociedad democrática. Madrid: Taurus Ediciones, 1984.

Díaz, Elías. Socialismo en Espana: El Partido y el Estado. Madrid: Editorial Mezquita, 1982.

Fernandes, Vasco da Gama. Do III Congresso de Aveiro à última campanha eleitoral. Lisboa, 1974.

Las Constituciones de España. Edición de Jorge de Esteban. Madrid: Taurus Ediciones, 1981.

Lucas Verdú, Pablo. Estado liberal de Derecho y Estado social de Derecho. Salamanca: Universidad de Salamanca, 1955.

Marcuse, Herbert. One-dimensional Man: studies in ideology of advanced industrial society. London and New York: Routledge, 2002.

Pinochet, Augusto. Discurso de Chacarillas. El Mercurio. 1977, 10-16 de Julio.

Shively, William Phillips. Power and choice: An introduction to political science. New York.: McGraw Hill Higher Education, 1991.

Tikhomirov, Yurii. The Law in the socialist law-governed state. (Zakon v sotsialysticheskom pravovom gosudarstve). Socialist law-governed state: problems and judgements. (Sotsialisticheskoe pravovoe gosudarstvo: problemy i suzhdeniia). Moscow: Institute of State and law, Academy of Sciences of USSR, 1989: 160-166. (In Russian).

Uma via original para o socialismo. Lisboa, 1974.

Yakushik, Valentin. An introduction to political science. (Vstup do politologiyi). Kyiv: Yurinkom Inter, 2012. (In Ukrainian).

Yakushik, Valentin. Issues of theory of revolutionary-democratic State. (Problemy teorii revoliutsionno-demokraticheskogo gosudarstva). Kiev: UMK VO, 1991. (In Russian).

Yakushik, Valentin. Problems of typology of a law-governed State. (Problemy tipologii pravovogo gosudarstva). Philosophical and Sociological Thought. (Filosofskaia $i$ sotsiologicheskaia mysl), No. 9-10, 1993: 177-195. (In Russian).

Yakushik, Valentin. Social-reformist version of a "law-governed State" theory and practices of the modern Portuguese constitutionalism (Sotsial-reformistsii variant teorii "pravovogo gosudarstva" i praktika sovremennogo portugalskogo konstitutsionalizma). Problems of Jurisprudence. (Problemy pravovedeniia, Issue 47, 1986: 31-39. (In Russian).

Yakushik, Valentin. The State of a transitional type (theoretical issues). (Gosudarstvo perehodnogo tipa (voprosy teorii)). Kiev: Lybid, 1991. (In Russian). 